\title{
The greening of South-South trade: levels, growth, and specialization of trade in clean energy technologies between countries in the global South
}

\section{CCEP Working Paper 2003 May 2020}

\section{Jorrit Gosens}

Crawford School of Public Policy, Australian National University

\begin{abstract}
Countries in the global South, or developing and emerging economies, are experiencing rapid economic growth, and increased economic integration with other countries in the global South, including trade. Some analysts have raised concerns that such South-South trade might encourage the use of outdated conventional energy technologies, and lock developing countries into high carbon growth paths. Here, trade data from the UN Comtrade database is analyzed with a gravity model of trade. Results show that levels of clean energy technologies in South-south trade were relatively low up until the first half of the 2010's, but that these are entirely comparable to North-North or other trade flows in recent years. The analysis thus finds no evidence to support concerns that South-South trade might encourage high carbon development. South-South trade contains particularly high levels of solar PV, hydropower, and electric two-wheeler technologies, whilst exporters in the global North are more competitive in markets for wind power equipment and electric vehicles. Trade in electric vehicles is the fastest growing class of clean energy technologies, and the dominance of Northern countries in their exports may mean that South-South trade could, in the foreseeable future, once again lag behind in levels of clean energy technologies.
\end{abstract}




\title{
Keywords:
}

South-South trade; sustainable development; renewable energy; gravity model; UN Comtrade

\section{Acknowledgements:}

This research was supported by Aalborg University (AAU Grant 771107), and by funding under the Energy Transition Hub at the Australian National University. These financiers had no involvement in research design or reporting.

\section{Suggested Citation:}

Gosens, J. (2020), The greening of South-South trade: levels, growth, and specialization of trade in clean energy technologies between countries in the global South, CCEP Working Paper 2003, May 2020. Crawford School of Public Policy, The Australian National University.

\author{
Address for Correspondence: \\ Jorrit Gosens \\ Research fellow \\ Centre for Climate Economics \& Policy \\ Crawford School of Public Policy \\ The Australian National University \\ Tel: +61 (2) 61250559 \\ Email: jorrit.gosens@anu.edu.au
}

The Crawford School of Public Policy is the Australian National University's public policy school, serving and influencing Australia, Asia and the Pacific through advanced policy research, graduate and executive education, and policy impact.

The Centre for Climate Economics \& Policy is an organized research unit at the Crawford School of Public Policy, The Australian National University. The working paper series is intended to facilitate academic and policy discussion, and the views expressed in working papers are those of the authors. Contact for the Centre: Prof Frank Jotzo, frank.jotzo@anu.edu.au 


\section{Introduction}

Global patterns of economic growth have substantially changed over the past few decades. Throughout most of the $20^{\text {th }}$ century, global economic activity was strongly concentrated in a small group of countries, labelled as either developed countries, highincome countries, advanced economies, the First World, or the Global North [1]. In recent decades, the GDP of developing countries, or the Global South (Figure 1), has on average grown at substantially higher pace than in the Global North, and has become an increasingly significant share of global economic output [2]. A group of so-called emerging economies in particular is experiencing rapid development, creating a world in which economic activity is less concentrated in a small group of countries, and transitioning to what the world bank calls a multipolar global economy [3].

This increasing economic activity has also meant stronger economic interaction and integration between countries in the global South [2], for example in increasing relevance of South-South Foreign Direct Investment $[4,5]$, South-South technology transfer $[6,7]$, or SouthSouth trade $[2,8]$; see also Figure 2.

Traditionally, analyses of South-South trade have focused on the apparent barriers to trade between developing countries, and the potential benefits for economic development from trade agreements to remove such barriers $[1,8,9]$. In recent years, as the increased economic activity in the Global South has inevitably also led to increased environmental pressure, analyses have increasingly focused on the potential environmental effects of SouthSouth trade, and ways to mitigate these [10-13]. With the strong global attention for climate change, this has naturally included a particular focus on South-South trade in energy technologies, and consequent emissions of greenhouse gasses [14-17].

Such previous analyses have included both pessimistic and optimistic assessments of the rise in South-South trade, or other economic collaboration, and resulting effects on the use of conventional or clean energy technologies, and/or the resulting effect on emissions of greenhouse gas emissions by countries in the global South.

One stream of thought holds that countries in the global North are the world's primary developers and suppliers of advanced, efficient, and environmentally sound technologies. Reducing the environmental impact of economic development in the global South, then, would be primarily dependent on the transfer of such environmentally sound technologies, including clean energy technologies $[18,19]$. This could occur, amongst others, through the transfer of knowledge or capabilities and resulting development of equipment manufacturing industries for clean energy technologies in the global South, or through the trade in 
equipment $[20,21]$. Further, countries in the global North are sometimes considered to be more attentive to possible negative environmental impacts of economic cooperation with or assistance to developing countries [22,23]. Economic integration between developing countries, then, would limit access to clean energy technologies and reduce scrutiny on environmental impacts, and thus encourage the use of outdated conventional energy technologies, and lock developing countries into high carbon growth paths.

Others have argued that countries in the global South have not only been rapidly catching up in developing industries for clean energy technologies, but have in fact been involved in their development from fairly early development stages [24], and are actively transferring clean energy technologies to other developing countries $[6,16]$. Whilst recognizing that there may be technological barriers to the adoption of advanced clean energy technologies, a number of analysts have further suggested that suppliers from the global South may be more understanding of the needs and capabilities of other Southern countries, and be able to provide more appropriate clean energy technologies, that may still substantially contribute to carbon emission reductions $[25,26]$.

Despite much debate and theorizing, and despite a wealth of more fine-grained analysis of particular transfer mechanisms, countries, industries, or effects of trade policies, few studies have used global datasets in an attempt to answer more generically whether or not South-South trade does indeed appear to have positive or detrimental environmental effects, when compared with trade flows between other countries $[14,17,27]$.

This paper aims to contribute to this discussion by analyzing global trade in clean energy technologies, and asking 1 ) does South-South trade contain lower or higher levels of clean energy technologies, when compared with other trade flows; 2 ) are those levels of clean energy technologies in South-South trade growing at a slower or faster pace, when compared with other trade flows; and 3) do these levels differ substantially between different types of clean energy technologies?

Results show that although trade in clean energy technologies in South-South trade flows has indeed long lagged behind when compared with other trade flows, this gap has been closed entirely in recent years. The analysis thus finds no evidence to support concerns that South-South trade might encourage high carbon development. South-South trade contains particularly high levels of solar photovoltaic (PV), hydropower, and electric two-wheeler technologies, and lower levels of wind power equipment and electric vehicles. As the trade in electric vehicles is the fastest growing class of clean energy technologies globally, the weak 
position of southern countries in this industry may mean that South-South trade, in the foreseeable future, will once again lag behind in levels of clean energy technologies.

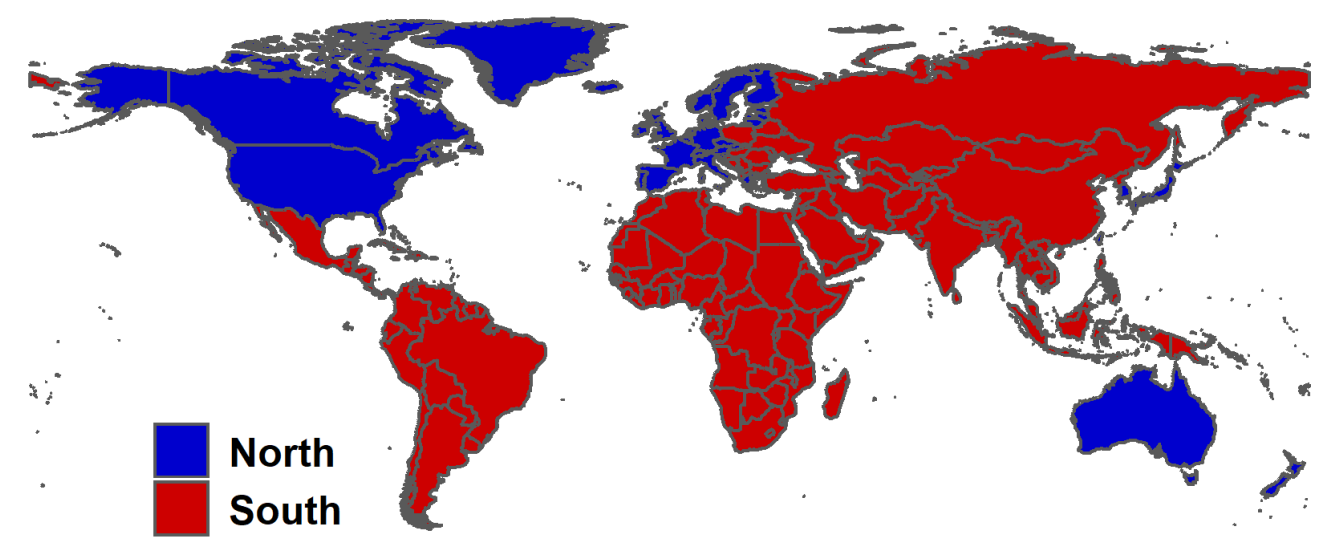

Figure 1. Map of the world with countries categorized as North or South.

Categorization according to IMF [28]; see Appendix A for specific list.

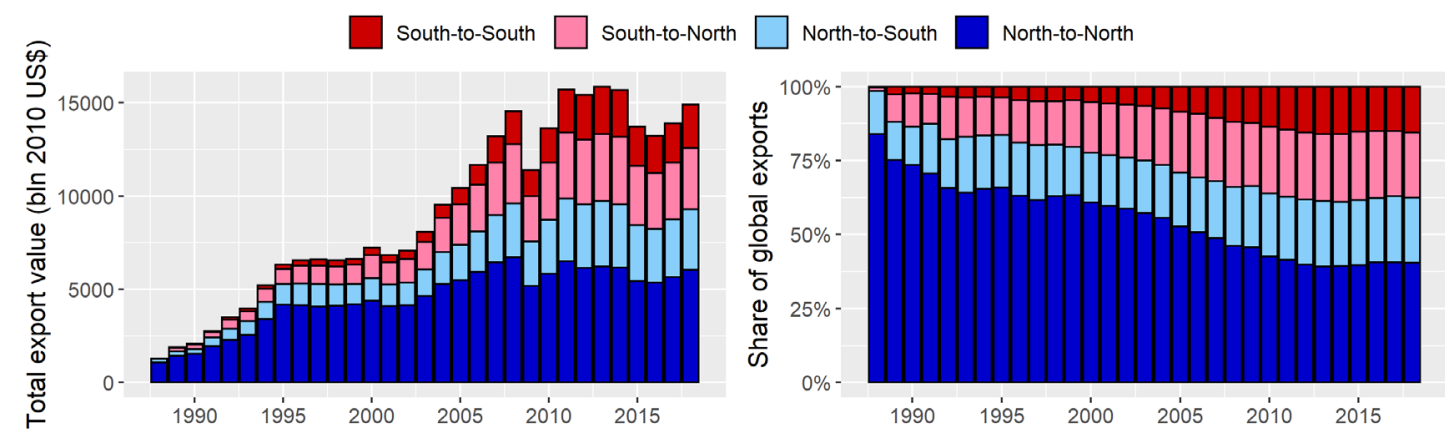

Figure 2. Total value of all exports, categorized by origin and destination in the global North or South. Total trade value in billion 2010 US\$ (left), and as a share of global exports (right). Data source: [29]. 


\section{Method and data}

\subsection{Defining the global North and South}

Literature on international relations, political science, and development studies has regularly conceptualized the world as being divided into a Global North and South [30]. This division indicates the distinct gap in economic development levels in countries to the North and South of a latitude of roughly $30^{\circ}$ North (with the exception of Australia and New Zealand) [1]. These Northern and Southern countries differ in levels of per capita income, levels of democracy, in having a history of being colonizers vs. colonized countries, as well as levels of integration and power in global economic institutions, flows of finance, and trade $[30,31]$. Countries in the South have usually seen lower exports, and more limited exports of (sophisticated) manufactured goods in particular $[1,8]$.

The North vs. South classification of countries closely overlaps with classification such as First/Second vs. Third world [32], high income vs. middle and low income countries [33], or Advanced vs. Emerging and Developing Economies [28]. Despite the regular use of the North vs. South division, few papers or reports provide exact definitions of what countries are classified as belonging to either group, nor is there a standard definition to refer to.

Here, 'the North' is defined as the 39 territories currently classified by the IMF as 'advanced economies' (Figure 1), with the South defined as the remainder of the full IMF list of 194 countries (for a full list see Appendix A). Use of the IMF list means that a number of dependent or associated territories such as the Cayman Islands, Curacao, the Marshall Islands, New Caledonia, Niue, St. Martin, the Virgin Islands etc. are excluded from the analysis, even though these territories report their trade as separate entities in the UN Comtrade database used here. They are excluded here because these territories often have vastly different income levels, and can be expected to have an entirely different composition of industry and exports from the countries they are associated with. Labelling the circa 50 such territories as either North or South would create a potential bias in the estimated export composition of either group. Note also that this is a static definition, i.e., it does not consider switching between e.g., Emerging Economies and Advanced Economies over the period of trade data analyzed here (1990-2018). Lastly, note that this means Russia and a number of other former Soviet Republics are not considered to be part of the North, in contrast with some traditional definitions [1]. The reason for doing so is that Russia has not been classified as a high-income country for all but three years during the period of trade data analyzed here (1990-2018)[34], and is usually grouped together with major emerging economies, or BRICS countries (Brazil, 
Russia, India, China, South Africa) in more recent discussions of global economic development trends [3].

\subsection{Defining trade flows of clean energy technologies}

Data on trade is collected from the UN Comtrade database, where countries report their imports and exports of goods, subdivided into circa 5,900 different categories ('headings') of the Harmonized Commodity Description and Coding Systems (HS) system [35]. These HS headings do not always follow precisely along the lines of the technologies of interest. Previous analyses of trade in renewable energy products, or more broadly of trade in environmentally friendly technologies, have therefore followed either of two approaches in selecting HS headings used to identify clean (energy) products.

The first approach is to select all headings of goods that may contain clean energy equipment or components used in their manufacture, even if the goods of interest might only be a small fraction of all goods traded under that specific heading. An example of this approach is to include HS headings for 'bearings' or 'steel structures' when analysing trade in wind power products $[36,37]$, or glass panes and aluminium structures when analysing trade in PV products $[12,38]$. Although it is true that bearings are used in wind turbines, and that wind turbine towers would likely be traded under the heading for steel structures, the bulk of bearings and steel structures will be used in products other than wind turbines.

The second approach is to select only those headings that uniquely or predominantly contain clean energy equipment or their components. An example of this approach is to limit the selection of HS headings to 'Electric generating sets; wind-powered' when analysing trade in wind power products $[14,39]$. This approach will classify only products used in the wind turbine industry as such, at the expense of disregarding components used in the industry, e.g., separate towers or turbine blades, that may also be traded under different HS headings.

Here, the more conservative second approach is used, with suitable HS classes identified by parsing studies that provide specific lists of HS classes to refer to clean energy technologies, including those mentioned above [12-14,36,39-43].

For PV, only the HS heading 854140 is used. This category includes PV cells and panels, but also other photosensitive semiconductor devices and light-emitting diodes (LEDs). This is the common approach in studies of trade in PV products $[14,15,44]$ because this is the HS heading under which all PV panels and cells will be traded, and because the misidentification of other products as PV panels or cells is likely limited. UNEP [14] utilized national customs data, which can be more fine-grained than the globally used HS classification, to identify that PV panels accounted for circa 81\% of goods exported in 2011 under HS heading 854140 from 
China (the world's largest exporter of PV panels), and for circa 70\% of US imports. For similar reasons, the analysis here will use HS heading 841919 , which includes domestic water heaters other than electric or gas-fired, as a proxy for solar water heaters, as is commonly done $[12,40,45]$. National level customs data identified that solar water heaters make up circa $95 \%$ of exports under HS heading 841919 from China (the world's largest exporter of these devices), although US imports under the heading include just 7.5\% solar water heaters [14].

Unfortunately, only a small number of countries has such more fine-grained domestic customs data for these products, and any analysis of global trade data will have to rely on the HS headings used in the Comtrade data $[39,41]$. These examples support the idea that these less fine-grained HS headings are at least sensible proxies for the technologies of interest in the analysis done here.

In the most recent revision of 2017 of the HS scheme, new headings were introduced for trade in hybrid or pure electric passenger cars, buses, and two-wheelers [35]. For the years prior to 2017, it is still possible to use a proxy to identify trade in electric cars or two-wheelers. Trade in cars and two-wheelers in earlier HS classification systems is sub-divided into categories with different engine capacities in cubic centimetre, and one additional class for cars or two-wheelers 'not elsewhere specified (n.e.s.)'. Trade reported under two-wheelers (n.e.s.), has grown rapidly each year since 2010 , but dropped by circa $85 \%$ since the introduction of the new HS heading for electric two-wheelers, making it fairly likely that most trade reported under the heading for two-wheelers (n.e.s.) prior to 2017 were actually electric-two-wheelers. For passenger cars, a similar drop of $75 \%$ can be seen in the 'not elsewhere specified' category when the HS classes for hybrid and electric vehicles were introduced. More details including figures are provided in Appendix B.

The analysis here will also compare shares of clean versus conventional energy products. Identification of those HS headings was done through a parsing of the full list of HS headings. It should be noted that a number of the reports referred to in this section classified HS headings for e.g., boilers, turbines, and generators as clean energy technologies on the basis that these may be used in biomass power generation [14,36,40,41]. Here, these headings are classified as conventional energy technologies on the basis that fossil power generation remains to be a far greater source of power generation worldwide, and trade under these headings may therefore be expected to predominantly contain goods for fossil power generation.

The final list of selected clean and conventional energy products selected in this way is presented in Table 1. 
Table 1. HS headings for clean and conventional energy technologies and products

\begin{tabular}{|c|c|c|c|}
\hline HS heading & Technology class & HS heading refers to & Period used \\
\hline 8410 & Clean power-Hydropower & $\begin{array}{lll}\begin{array}{l}\text { Hydraulic } \\
\text { components }\end{array} & \text { turbines and } \\
\end{array}$ & All \\
\hline 850231 & Clean power - Wind power & $\begin{array}{l}\text { Wind turbines, complete } \\
\text { generating sets }\end{array}$ & Since 1996 \\
\hline 854140 & Clean power - PV & $\begin{array}{ll}\text { Photosensitive } & \text { apparatus, } \\
\text { including PV cells } & \\
\end{array}$ & All \\
\hline 841919 & $\begin{array}{l}\text { Clean heat supply - Solar hot } \\
\text { water }\end{array}$ & $\begin{array}{l}\text { Water heaters for domestic and } \\
\text { other purposes, not using gas or } \\
\text { electricity }\end{array}$ & All \\
\hline 2207 & Clean fuels & Ethanol & All \\
\hline 3826 & Clean fuels & Bio-diesel & Since 2012 \\
\hline 4401,4402 & Clean fuels & $\begin{array}{l}\text { Solid biomass; fuel wood and } \\
\text { charcoal }\end{array}$ & All \\
\hline 870220,870230 & Clean transport - EV & Hybrid electric busses & Since 2017 \\
\hline 870240 & Clean transport - EV & Pure electric busses & Since 2017 \\
\hline 870360,870370 & Clean transport - EV & Hybrid passenger cars & Since 2017 \\
\hline 870380 & Clean transport - EV & Pure electric passenger cars & Since 2017 \\
\hline 871160 & Clean transport - EV & Electric two-wheelers & Since 2017 \\
\hline 870390 & Clean transport - EV & $\begin{array}{l}\text { Passenger cars without a defined } \\
\text { engine capacity, used as proxy for } \\
\text { hybrid/electric vehicles }\end{array}$ & Up to 2017 \\
\hline 871190 & Clean transport - EV & $\begin{array}{l}\text { Two-wheelers without a defined } \\
\text { engine capacity, used as proxy for } \\
\text { electric two-wheelers }\end{array}$ & Up to 2017 \\
\hline 8401 & Conventional power generation & $\begin{array}{l}\text { Nuclear reactors and fuel } \\
\text { elements }\end{array}$ & All \\
\hline $8402,8403,8404$ & Conventional power generation & Boilers \& components & All \\
\hline 8405 & Conventional power generation & Generators for producer gas & All \\
\hline 8406 & Conventional power generation & Steam turbines & All \\
\hline 8411 & Conventional power generation & Gas turbines & All \\
\hline 8416 & Conventional power generation & $\begin{array}{l}\text { Furnace burners for liquid fuel, } \\
\text { pulverised solid fuel or gas }\end{array}$ & All \\
\hline 8417 & Conventional power generation & $\begin{array}{l}\text { Furnaces and ovens, including } \\
\text { incinerators }\end{array}$ & All \\
\hline 841911 & Conventional heat supply & $\begin{array}{l}\text { Water heaters for domestic and } \\
\text { other purposes, gas-fired }\end{array}$ & All \\
\hline 8502 & Conventional power generation & Electric generating sets & All \\
\hline $8503,850161-850164$ & Conventional power generation & $\begin{array}{l}\text { Electric generators (AC) and } \\
\text { components }\end{array}$ & All \\
\hline $8407,8408,8409$ & Conventional transport & $\begin{array}{l}\text { Internal combustion engines and } \\
\text { components }\end{array}$ & All \\
\hline $8701-8711,8714$ & Conventional transport & Vehicles and components & All \\
\hline 27 & Conventional fuels & $\begin{array}{l}\text { Mineral fuels, oils and products of } \\
\text { their distillation }\end{array}$ & All \\
\hline
\end{tabular}

Notes: a) see explanation in the text and in Annex A. 


\subsection{Model specification}

In the literature on international trade, the most common approach to comparing bilateral trade flows between different nations is with a so-called gravity model of trade $[46,47]$. In its most basic form, such a model considers the volume of trade between two nations to relate positively with the size of the economy (GDP) of both the exporter and importer, and negatively with the distance between the two nations [48]. The model gets its name from the analogy with the function for the gravitational force between two objects, which increases with each of the objects' masses, and decreases with the distance between them. Applications of such a gravity model would further include a variable of interest, with the main strands of this literature focused on analyzing the impact of trade agreements or currency unions on total trade between countries [49-51], and a number of control variables that capture other reasons why trade between nations may experience friction $[52,53]$.

\subsubsection{Variables of interest}

The aim of current study is to identify whether there is any difference in the share of clean energy technologies in trade flows between two countries in the global South, when compared with trade flows between other countries.

The outcome (dependent) variable in this model is the value of trade flows between different countries in different product categories. The dataset used contains the value of exports for each combination of exporter country, importer country, year, and good (the different headings listed in Table 1). The source data used for this analysis, the UN Comtrade database [29], provides two values, both exports and imports, for each country pair, year, and HS heading. That is, it lists both the value of exports of e.g., PV panels from China to the US, and also the value of US imports of PV panels from China. Here, the value reported for exports is used, as this refers to the value of the goods themselves, whilst the value reported for imports may include transport and insurance costs $[14,54]$.

The key explanatory (independent) variables are a set of dummies for country grouping and tech class. With countries classified as either North or South (section 2.1), trade flows can be classified as either North-to-North, North-to-South, South-to-North, and Southto-South. Including dummy variables for these 4 different trade flows allows estimating the relative size of South-to-South (or North-to-South, South-to-North) trade flows in any product, when compared with North-to-North trade. Secondly, using HS headings from Table 1, trade flows can be classified as either clean energy technologies, or anything else. Dummy variables for these two types of products allow estimating the average relative size of trade flows of clean energy goods, when compared with trade flows in any other goods, between any two 
countries. Third, by creating an interaction variable between these two classifications, and including main effects (the dummies described above), allows estimating the relative size of trade flows of clean energy goods in South-to-South (or North-to-South, South-to-North) trade flows, when compared with trade flows of clean energy goods in North-to-North trade.

\subsubsection{Estimation method, control variables and fixed effects}

Traditionally, gravity models of trade have been estimated with ordinary least squares (OLS), with logged versions of both outcome (trade value) and explanatory (GDP of exporter and importer) variables [55]. These models have further included a set of control variables that represent 'distance' between country pairs, in geographic, economic, institutional, or cultural terms, for example with variables indicating average transport distances between major cities in both countries, having a shared border, shared currency, shared language, shared colonial past, or being part of a common trade agreement $[46,47]$. It has further become fairly standard practice to capture 'multilateral resistance', or the average barrier to trade a country experiences with any partner country, rather than barriers between specific country pairs, with fixed effects for both exporter and importer countries [52].

In more recent years, a number of different estimation techniques has been favoured over the traditional dependency on OLS, with the use of the Poisson pseudo-maximumlikelihood (PPML) estimator increasingly becoming the norm $[46,47,56]$. Amongst the benefits of this method is that it can readily handle trade flows that are equal to zero (not trade between two countries), as the method does not require the trade flows to be logged, as in the traditional OLS method, thus reducing bias. The method is further resistant to bias and inconsistency resulting from heteroscedasticity, stemming from relatively large errors in reporting in smaller trade flows, for example for smaller countries $[46,47,55]$. Both issues are particularly relevant to the analysis here, as clean energy technologies will more often be small or zero, when compared to total bilateral trade volumes that are usually analysed in gravity models of trade. There has also been progress in methods for properly including the 'multilateral resistances', which have previously usually been corrected for with various (combinations of) fixed effects for time, exporter, importer, or country-pairs. More recently, it has been concluded that the gold standard for removing bias and inconsistency in the estimator, is to include fixed effects for each combination of exporter and year (time-variant country dummies), importer and year, as well as country-pair fixed effects $[57,58]$. Such proper specification may cause certain variables to be found to no longer be significant, and may even lead to sign flipping, when compared with the smaller sets of fixed effects usually included $[57,58]$. The inclusion of country-pair fixed effects has long been a problem as it 
requires substantial computational resources; for a global dataset with circa 200 countries, including country-pair fixed effects would require 40,000 dummy variables [49,59]. Recent computational advances enable exactly such estimations with extraordinary numbers of fixed effects in a limited amount of time $[49,60]$. The only downside of including all these fixed effects is that they absorb much of the usual explanatory variables; GDP, distance, or other country-pair characteristics are perfectly collinear with either the country-time or countrypair fixed effects. Although methodologically more correct, this makes interpretation of result somewhat less intuitive.

For the analysis here, estimates will be provided both without the full set of fixed effects, thus preserving the coefficients for the traditional set of gravity model variables, as well as an estimate where such coefficients are absorbed by the full set of fixed effects. Estimations are done in Stata 15.1 using the package ppml_hdfe [60].

\subsection{Data collection and description}

Data on trade flows was acquired from UN Comtrade, via the bulk download facility, with updates through December of 2019 [29]. Data on country level economic indicators was acquired from the World Development Indicators (WDI) dataset from the World Bank [33]. Data on gravity model control variables was acquired from the Gravity Dataset from CEPII [61]. Details on operationalization and sources for all variables are provided in Appendix B. 


\section{Results}

This section will first present total exports and percentage shares of clean energy technologies in South-South trade, and estimate if these differ significantly from exports of clean energy technologies in other trade flows (Section 3.1). In a next step, the pace of growth of these percentage shares in flows between Northern and Southern countries is compared (Section 3.2), followed by a comparison of exports in individual clean energy technologies (Section 3.3).

\subsection{Volumes and shares of South-South trade in clean energy technologies}

\subsubsection{Aggregated volumes and shares of trade in clean energy technologies}

The historical development of the total dollar value and shares of clean energy technologies in different trade flows between Northern and Southern countries are presented in Figure 3. The top row of this figure shows that the total trade value in clean energy goods between in South-South trade has long been marginal, but has grown fairly rapidly since circa 2010. The figure further shows that in recent years, Northern and Southern countries export roughly similar amounts of clean energy goods to Southern countries, and that the South has become a substantial supplier of clean energy goods imported by the North. The figure further shows that global trade in clean energy goods is dominated by exports of PV panels [14], and that the rise of the growth of South-South trade in clean energy goods is due in large part to the shift of PV manufacturing from Northern to Southern countries, in particular from the U.S., Japan, and Germany, towards China, around the year 2010 [14,62].

In terms of percentage shares of exports (bottom row in Figure 3), the recent growth in exports between Southern countries is much more impressive. In recent years, the percentages of clean energy technologies in South-South trade are already very close to the levels in North-North trade, and higher than the share of clean energy goods imported by the South from Northern countries. Again, it is also clear that that North-North trade contains a more diversified portfolio of clean energy technologies, whilst South-South trade is mostly PV. Note that the percentage shares presented in Figure 3 are percentages of exports of manufactured goods, see section 3.1.3 for more on this. Also note that the steep fall in SouthNorth exports, in 2012, is likely mostly due to trade restrictions against Chinese PV panels imposed by the US and the EU $[63,64]$. 


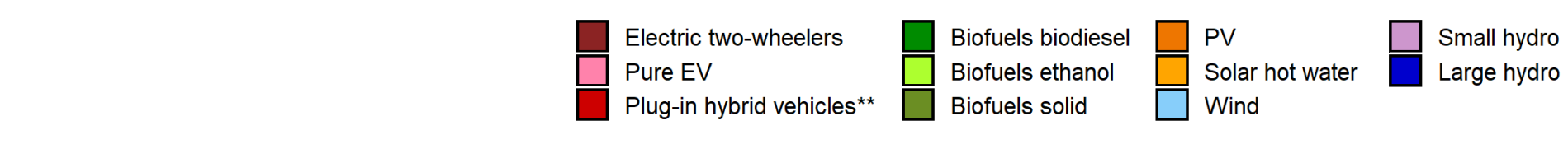

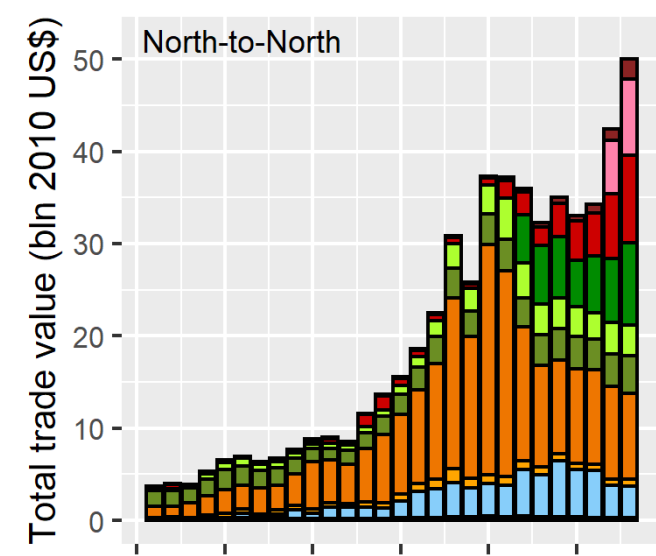

$\begin{array}{llllll}1990 & 1995 & 2000 & 2005 & 2010 & 2015\end{array}$

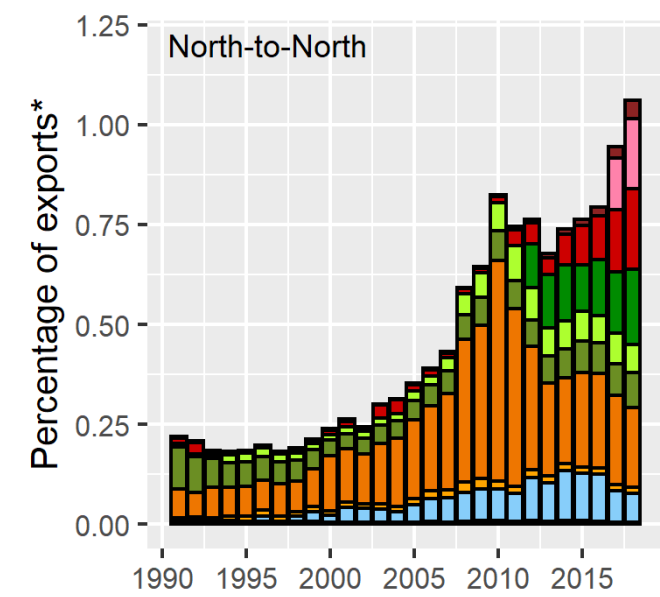

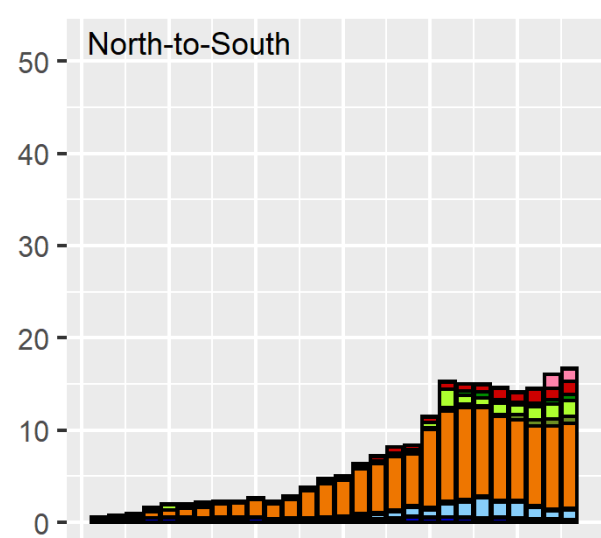

$\begin{array}{llllll}1990 & 1995 & 2000 & 2005 & 2010 & 2015\end{array}$

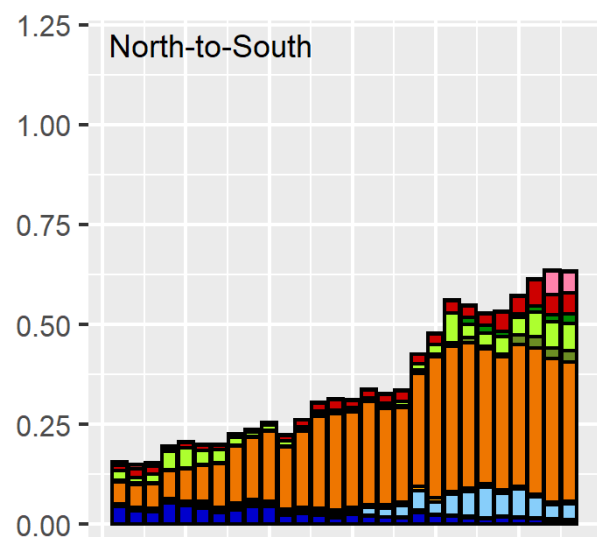

$1990 \quad 199520002005201020^{\prime} 15$

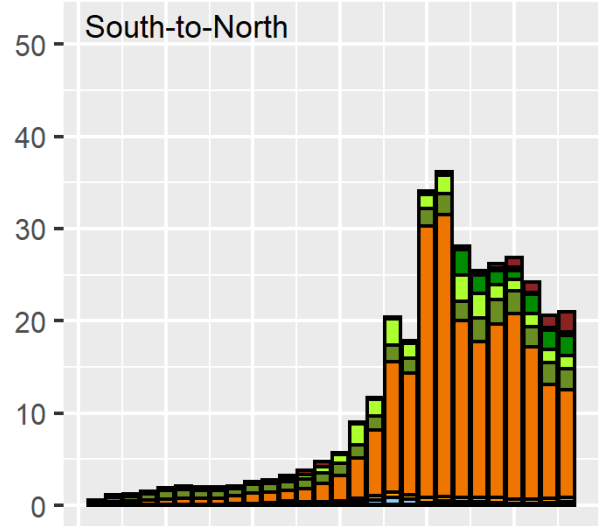

199019952000200520102015

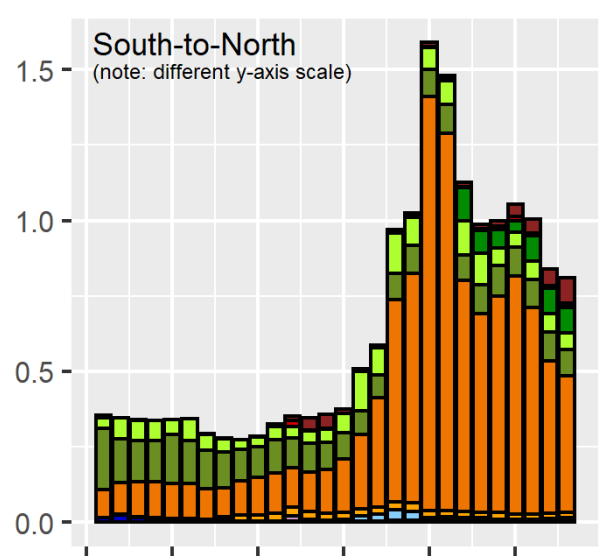

$1990 \quad 1995 \quad 2000 \quad 2005 \quad 201020^{\prime} 15$

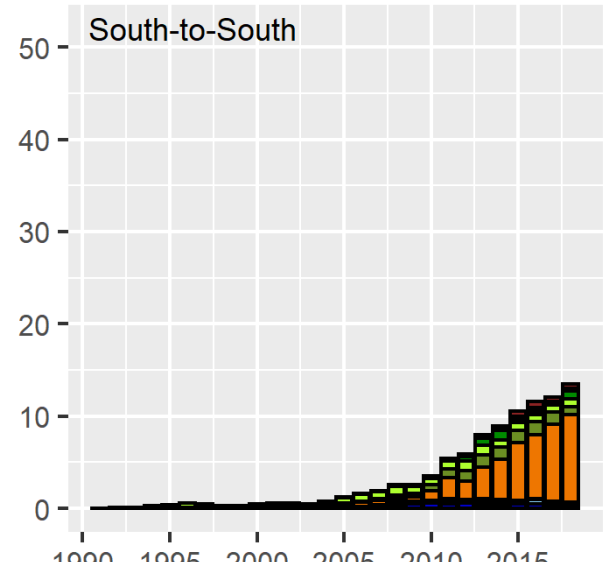

199019952000200520102015

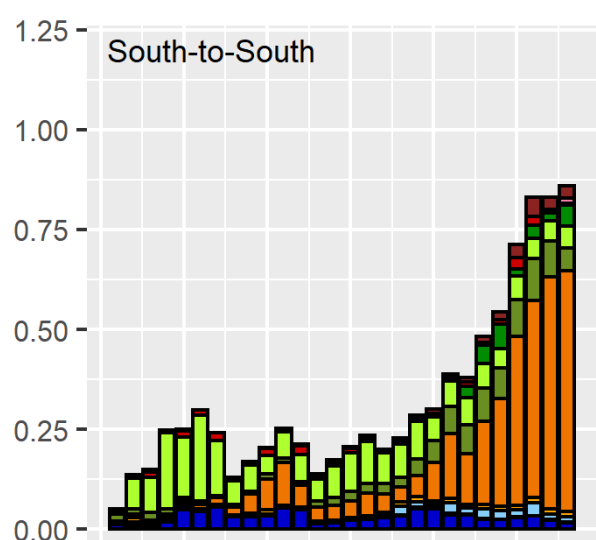

$1990 \quad 19952000200520^{\prime} 1020^{\prime} 15$

Figure 3. Exports of clean energy goods, by year and direction of trade flow. Total value in constant 2010 US\$ (top row), and as percentage of exports of manufactured goods (bottom row). Note: ${ }^{*}$ ) percentage of exports of all manufactured goods; ${ }^{* *}$ ) category plug-in hybrid vehicles contains both pure EV and plug-in hybrid vehicles prior to 2017. 


\subsubsection{Average levels of South-South trade in clean energy technologies}

The total, or aggregated, volumes and shares of exports between different country groups, discussed above, do not say much about how much clean energy technologies the average Southern country exports to other Southern countries, when compared with trade between Northern countries. This is determined in the regression analysis presented in Table 2 , where the value of exports between individual countries is regressed on a number of country characteristics, whether the exporter and importer are in the global North or South, and whether the exported goods were clean energy goods or not. The four different models presented in Table 2 differ only in the types of fixed effects included to represent the friction to trade between different countries (explanation in Section 2.3.2). This regression includes data only for the years 2014 through 2018, in order to reflect the relatively current status quo of trade in clean energy technologies between different country groups; the question of how this has developed over the past decades is dealt with in Section 3.2.

Results in Table 2 show the expected effects for the basic variables of the gravity model: trade is higher between countries with larger economies, and lower when countries are farther away from each other. Estimates for the other gravity model control variables, which indicate of the countries share a border, colonial past, currency or language have mixed results in the models without any fixed effects (model no. 1 in Table 2) and with time-varying country fixed effects (no. 2). Models no. 3 and 4 do not produce any estimates for these factors as these are absorbed by the country-pair fixed effects included in these models. The results for the trade agreements, i.e., whether the exporter and importer countries are both members of the WTO, EU, or a regional Trade Agreement (RTA), differ in significance, sign, and point estimates between the four models, highlighting the results from recent work on the inclusion of these fixed effects on possible conclusions derived from the effect of trade agreements on total trade flows $[49,60]$.

When looking at the variables of interest for the research question here, results firstly show that the dummy variable for exports in clean energy goods is strongly negative, i.e., that such exports are far smaller than exports of all other manufactured goods, used as the reference level here (for other reference levels, see Section 3.1.3). This is unsurprising as these clean energy goods constituted less than $1 \%$ of total exports of manufactured goods in recent years (Figure 3).

After also correcting for the average size of exports between different country groups, either with the dummy variables for North-to-North, South-to-South exports etc., or with the fixed effects that absorb these effects in models no. 2 to 4 in Table 2, the last 4 interaction 
variables reveal differences in the average size of exports of clean energy goods between different country groups. The coefficients for those variables indicate that, when compared with clean energy exports in North-to-North trade flows, the value of clean energy exports from South-to-South or from South-to-North were not significantly different, whilst such exports from North-to-South were significantly smaller.

These results, which indicate the average levels of clean energy exports between individual countries in South-South trade, are thus comparable to the results for exports aggregated for all South-South trade, and for the other flows in clean energy technologies, as reported in Figure 3. There is little difference in both average trade levels for individual countries or aggregate trade volumes in clean energy technologies in North-North, SouthNorth, or South-South trade flows, whilst North-South flows are smaller. This implies that these aggregate levels of trade in clean energy technologies are not due to high levels of trade between a very limited number of exporters and importers in either of these types of trade flows.

Lastly, the results reported in Table 2 for the interaction variables are perfectly similar across all 4 models, likely because the fixed effects absorb country or country-pair characteristics, whilst these interaction variables refer to country groups. Because of the similarity in the estimates for these key variables, and because it is the theoretically most accurate, the model specification used in model no. 4 will be used throughout the remainder of this paper, and results reported only for those variables for which a coefficient is produced with this type of model specification. 
Table 2. Determinants of the value of exports for different technology classes and between different country groups (2014-2018)

\begin{tabular}{|c|c|c|c|c|}
\hline $\begin{array}{l}\text { Outcome variable: } \\
\text { total value of exports }\end{array}$ & (1) & (2) & (3) & (4) \\
\hline \multirow[t]{2}{*}{$\mathrm{GDP}_{\exp } * \mathrm{GDP}_{\text {imp }}$} & $.8955^{* * *}$ & 0 & $.3413^{* * *}$ & 0 \\
\hline & (34.152) & (.) & $(3.262)$ & (.) \\
\hline \multirow[t]{2}{*}{ Distance (weighted) } & $-.7399^{* * *}$ & $-.7522^{* * *}$ & 0 & 0 \\
\hline & $(-14.186)$ & $(-21.845)$ & (.) & (.) \\
\hline \multirow[t]{2}{*}{ Shared border } & $.5582^{* * *}$ & $.3861^{* * *}$ & 0 & 0 \\
\hline & (3.878) & (6.118) & (.) & (.) \\
\hline \multirow[t]{2}{*}{ Shared colonial past } & $-.2121^{* *}$ & $.2004^{* *}$ & 0 & 0 \\
\hline & $(-2.058)$ & $(2.207)$ & (.) & (.) \\
\hline \multirow[t]{2}{*}{ Common currency } & -.04952 & -.08532 & 0 & 0 \\
\hline & $(-0.424)$ & $(-0.992)$ & (.) & (.) \\
\hline \multirow[t]{2}{*}{ Common language } & $.4209^{* * *}$ & .09325 & 0 & 0 \\
\hline & $(4.725)$ & (1.344) & (.) & (.) \\
\hline \multirow[t]{2}{*}{ Both WTO members ${ }^{\mathrm{a}}$} & $.8607^{* * *}$ & $1.304^{* * *}$ & $-.185^{* * *}$ & .2059 \\
\hline & (7.280) & (3.313) & $(-5.906)$ & $(1.037)$ \\
\hline \multirow[t]{2}{*}{ Both EU members ${ }^{a}$} & -.09842 & $.2527^{* *}$ & 0 & 0 \\
\hline & $(-0.843)$ & (2.478) & (.) & (.) \\
\hline \multirow[t]{2}{*}{ Common RTA ${ }^{b}$} & $.4389^{* * *}$ & $.4412^{* * *}$ & $.1551^{* *}$ & $.1808^{* *}$ \\
\hline & $(5.045)$ & (7.181) & (1.984) & $(2.323)$ \\
\hline North-to-North exports & \multicolumn{4}{|c|}{ Reference level (omitted due to perfect collinearity) } \\
\hline \multirow[t]{2}{*}{ North-to-South exports } & $.3357^{* *}$ & .1088 & 0 & 0 \\
\hline & $(2.334)$ & $(1.277)$ & (.) & (.) \\
\hline \multirow[t]{2}{*}{ South-to-North exports } & $.3275^{*}$ & 0 & 0 & 0 \\
\hline & $(1.814)$ & (.) & (.) & (.) \\
\hline \multirow[t]{2}{*}{ South-to-South exports } & $.1987^{*}$ & 0 & 0 & 0 \\
\hline & $(1.686)$ & (.) & (.) & (.) \\
\hline $\begin{array}{l}\text { All manufactured goods except } \\
\text { clean energy goods }\end{array}$ & \multicolumn{4}{|c|}{ Reference level (omitted due to perfect collinearity) } \\
\hline \multirow[t]{2}{*}{ Clean energy goods } & $-4.583^{* * *}$ & $-4.583^{* * *}$ & $-4.583^{* * *}$ & $-4.583^{* * *}$ \\
\hline & $(-66.586)$ & $(-66.586)$ & $(-66.585)$ & $(-66.585)$ \\
\hline Clean energy exports, $\mathrm{N}$-to- $\mathrm{N}$ & \multicolumn{4}{|c|}{ Reference level (omitted due to perfect collinearity) } \\
\hline \multirow[t]{2}{*}{ Clean energy exports, $\mathrm{N}$-to-S } & $-.4234^{* * *}$ & $-.4234^{* * *}$ & $-.4234^{* * *}$ & $-.4234^{* * *}$ \\
\hline & $(-3.442)$ & $(-3.442)$ & $(-3.442)$ & $(-3.442)$ \\
\hline \multirow[t]{2}{*}{ Clean energy exports, S-to- $\mathrm{N}$} & -.02197 & -.02197 & -.02197 & -.02197 \\
\hline & $(-0.135)$ & $(-0.135)$ & $(-0.135)$ & $(-0.135)$ \\
\hline \multirow[t]{2}{*}{ Clean energy exports, S-to-S } & -.2712 & -.2712 & -.2712 & -.2712 \\
\hline & $(-1.610)$ & $(-1.609)$ & $(-1.609)$ & $(-1.609)$ \\
\hline \multirow[t]{2}{*}{ Constant } & $-22.99^{* * *}$ & $27.64^{* * *}$ & 4.402 & $23.23^{* * *}$ \\
\hline & $(-14.805)$ & $(55.589)$ & $(0.748)$ & $(116.742)$ \\
\hline Observations & 333792 & 256242 & 212490 & 192484 \\
\hline Fixed effects & None & Country-time & $\begin{array}{l}\text { Country-pair \& } \\
\text { time }\end{array}$ & $\begin{array}{l}\text { Country-time } \& \\
\text { country-pair }\end{array}$ \\
\hline
\end{tabular}

t statistics in parentheses

$* \mathrm{p}<0.10, * * \mathrm{p}<0.05, * * * \mathrm{p}<0.01$

Note: estimated with ppml, with standard errors clustered on country-pairs; 0 values for coefficients are due to the effect being absorbed by the country-time or country-pair fixed effects; difference in number of observations across models is due to increasing numbers of observations that are either singletons or separated by a fixed effect; a) WTO-membership has very little and EU-membership has no variation over the period of data included here 
(2014 to 2018), so coefficients for these variables for those models that include country-pair fixed effects (no. 3 \& 4) are of limited value; b) Regional Trade Agreement.

\subsubsection{Different reference levels for determining relative levels of trade in clean energy technologies}

When determining the relative levels of trade in clean energy technologies in SouthSouth versus North-North or other trade flows, the most obvious reference level would be to compare such exports with exports in all other goods. Developing countries, however, are known to export relatively higher shares of agricultural products, and lower shares of manufactured goods, largely due to their more limited manufacturing capabilities $[8,14]$. Using all exports as a reference level would therefore provide conclusions that say more about how manufacturing capabilities compare between different country groups, rather than how strongly these countries' manufacturing sector is focused on clean-tech, or specifically on clean energy technologies. A reference level that is perhaps even more precise would be to compare exports of clean energy technologies with exports of conventional energy technologies.

These three reference levels are compared in Table 3. The reference level in Model 1 in that table are all other exports, whilst model 2 compares with all other manufactured goods, i.e., excluding trade in agricultural products (HS chapters 1-24), minerals and fossil fuels (chapters 25-27), and miscellaneous products (chapters 97-98), and model 3 compares with conventional energy products as described in Table 1.

These results show that exports of clean energy technologies, relative to exports of all goods, were significantly lower in South-South than in North-North trade flows (model 1). They were, however, insignificantly different when regarding clean energy exports, relative to trade in manufactured goods (model 2, as also reported in Section 3.1.2), but borderline significantly higher when regarding exports of clean energy technologies relative to exports in conventional energy technologies (model 3). This is because, while exports of clean energy technologies make up similar shares in both North-North and South-South trade flows in recent years (Figure 3), conventional energy technologies make up a substantially lower share of in South-South trade flows (Figure 4). This graph further shows that exports of clean energy vehicles form a minute share of all vehicle exports, with any visible share only in North-North trade in recent years (Figure 4, middle row). Trade in power generation technologies, however, has seen a substantial shift towards clean energy technologies, with the largest shares of clean vs conventional energy technologies in South-North and South-South trade flows (Figure 4, bottom row). These results therefore indicate that there is very little reason to presume that 
the increasing economic integration between countries in the global South will encourage these countries to get locked in to more carbon-intense development patterns.

Table 3. Comparison of the value of exports of clean energy technologies between different country groups, versus different baselines (2014-2018)

\begin{tabular}{|c|c|c|c|}
\hline \multirow[b]{2}{*}{$\begin{array}{l}\text { Outcome variable: } \\
\text { total value of exports }\end{array}$} & (1) & (2) & (3) \\
\hline & $\begin{array}{l}\text { Clean energy vs. all } \\
\text { exports }\end{array}$ & $\begin{array}{l}\text { Clean energy vs. all } \\
\text { manufactured goods }\end{array}$ & $\begin{array}{l}\text { Clean energy vs. } \\
\text { conventional energy }\end{array}$ \\
\hline $\begin{array}{l}\text { Traditional gravity model } \\
\text { variables }\end{array}$ & \multicolumn{3}{|c|}{ Omitted (absorbed by fixed effects) } \\
\hline \multirow[t]{2}{*}{ Both WTO members } & $-.2942^{*}$ & .2059 & -.1976 \\
\hline & $(-1.780)$ & $(1.037)$ & $(-0.615)$ \\
\hline \multirow[t]{2}{*}{ Common RTA } & $.1452^{* * *}$ & $.1808^{* *}$ & .009313 \\
\hline & (2.809) & $(2.323)$ & $(0.135)$ \\
\hline $\begin{array}{l}\text { All goods except clean energy } \\
\text { goods }\end{array}$ & \multicolumn{3}{|c|}{ Reference level (omitted due to perfect collinearity) } \\
\hline \multirow[t]{2}{*}{ Clean energy goods } & $-4.821^{* * *}$ & $-4.583^{* * *}$ & $-2.828^{* * *}$ \\
\hline & $(-66.836)$ & $(-66.585)$ & $(-28.427)$ \\
\hline Clean energy exports, $\mathrm{N}$-to- $\mathrm{N}$ & \multicolumn{3}{|c|}{ Reference level (omitted due to perfect collinearity) } \\
\hline \multirow[t]{2}{*}{ Clean energy exports, $\mathrm{N}$-to-S } & $-.3931^{* * *}$ & $-.4234^{* * *}$ & -.1536 \\
\hline & $(-3.032)$ & $(-3.442)$ & $(-0.741)$ \\
\hline \multirow[t]{2}{*}{ Clean energy exports, S-to-N } & -.03079 & -.02197 & $.6368^{*}$ \\
\hline & $(-0.199)$ & $(-0.135)$ & $(1.666)$ \\
\hline \multirow[t]{2}{*}{ Clean energy exports, S-to-S } & $-.4114^{* *}$ & -.2712 & $.4257^{*}$ \\
\hline & $(-2.267)$ & $(-1.609)$ & $(1.929)$ \\
\hline \multirow[t]{2}{*}{ Constant } & $23.79 * * *$ & $23.23 * * *$ & $22.18 * * *$ \\
\hline & $(145.936)$ & $(116.742)$ & (69.724) \\
\hline Observations & 203736 & 192484 & 132920 \\
\hline Fixed effects & $\begin{array}{l}\text { Country-time \& country- } \\
\text { pair }\end{array}$ & $\begin{array}{l}\text { Country-time \& country- } \\
\text { pair }\end{array}$ & $\begin{array}{l}\text { Country-time \& country- } \\
\text { pair }\end{array}$ \\
\hline
\end{tabular}

$t$ statistics in parentheses

${ }^{*} p<0.10,{ }^{* *} p<0.05,{ }^{* * *} p<0.01$

See also the notes with Table 1. 

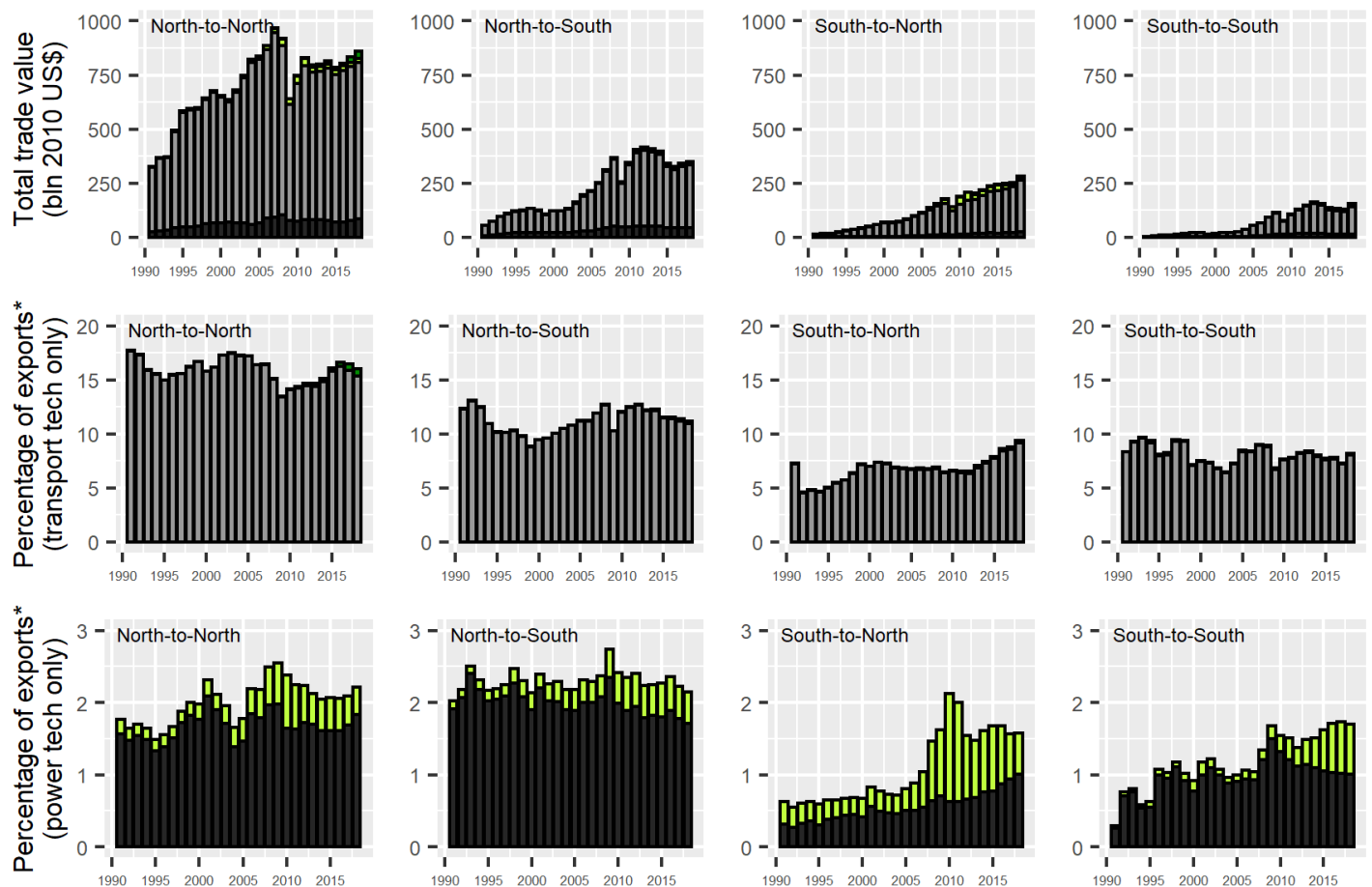

Figure 4. Trade in conventional and clean energy goods, by year and direction of trade flow. Total value in constant 2010 US\$ (top row), and as percentage of total exports of manufactured goods, for clean and conventional transport technologies (middle row), and clean and conventional power generation technologies (bottom row). Note: ${ }^{*}$ ) percentage of exports of all manufactured goods. 


\subsection{Growth of South-South trade in clean energy technologies}

In results up to this point, comparisons of the relative levels of clean energy technologies in South-South trade with such levels in other trade flows, regarded only the last five years of data available, or years 2014 to 2018, in order to make statements about the recent status quo. In table 4, the same comparison is made for the two 5 -year periods leading up to that.

Results reveal that up until recently, South-South trade had significantly lower levels of clean energy technologies, but not anymore in the latest 5-year period. This implies that the growth of trade in clean energy technologies between countries in the South over this period has outpaced such growth in North-North trade. It also shows that concerns over the possible carbon-intense development patterns arising from increasing economic integration between countries in the global South would have been a valid concern up until recently, but not any longer.

Table 4. Comparison of the value of exports of clean energy technologies between different country groups, in different time periods

\begin{tabular}{|c|c|c|c|}
\hline & (1) & (2) & (3) \\
\hline $\begin{array}{l}\text { Outcome variable: } \\
\text { total value of exports }\end{array}$ & 2005-2009 & 2010-2014 & 2014-2018 \\
\hline $\begin{array}{l}\text { Traditional gravity model } \\
\text { variables }\end{array}$ & \multicolumn{3}{|c|}{ Omitted (absorbed by fixed effects) } \\
\hline \multirow[t]{2}{*}{ Both WTO members } & .000778 & $-.5567^{*}$ & .2059 \\
\hline & $(0.015)$ & $(-1.737)$ & $(1.037)$ \\
\hline \multirow[t]{2}{*}{ Common RTA } & $.0741^{* * *}$ & $.1149^{*}$ & $.1808^{* *}$ \\
\hline & $(2.736)$ & $(1.765)$ & $(2.323)$ \\
\hline $\begin{array}{l}\text { All manufactured goods except } \\
\text { clean energy goods }\end{array}$ & \multicolumn{3}{|c|}{$\begin{array}{l}\text { Reference level (omitted due to perfect } \\
\text { collinearity) }\end{array}$} \\
\hline \multirow[t]{2}{*}{ Clean energy goods } & $-5.333^{* * *}$ & $-4.887^{* * *}$ & $-4.583^{* * *}$ \\
\hline & $(-59.456)$ & $(-68.400)$ & $(-66.585)$ \\
\hline Clean energy exports, $\mathrm{N}$-to- $\mathrm{N}$ & \multicolumn{3}{|c|}{$\begin{array}{l}\text { Reference level (omitted due to perfect } \\
\text { collinearity) }\end{array}$} \\
\hline \multirow[t]{2}{*}{ Clean energy exports, N-to-S } & $-.3171^{* *}$ & $-.3582^{* *}$ & $-.4234^{* * *}$ \\
\hline & $(-2.005)$ & $(-2.429)$ & $(-3.442)$ \\
\hline \multirow[t]{2}{*}{ Clean energy exports, S-to- $\mathrm{N}$} & $.4225^{*}$ & $.5041^{* * *}$ & -.02197 \\
\hline & $(1.876)$ & $(2.684)$ & $(-0.135)$ \\
\hline \multirow[t]{2}{*}{ Clean energy exports, S-to-S } & $-.6176^{* * *}$ & $-.5611^{* * *}$ & -.2712 \\
\hline & $(-3.828)$ & $(-3.955)$ & $(-1.609)$ \\
\hline \multirow[t]{2}{*}{ Constant } & $23.28^{* * *}$ & $23.92^{* * *}$ & $23.23^{* * *}$ \\
\hline & (399.963) & $(76.853)$ & $(116.742)$ \\
\hline Observations & 201754 & 209224 & 192484 \\
\hline Fixed effects & $\begin{array}{l}\text { Country-time } \\
\& \text { country-pair }\end{array}$ & $\begin{array}{l}\text { Country-time } \\
\& \text { country-pair }\end{array}$ & $\begin{array}{l}\text { Country-time } \\
\& \text { country-pair }\end{array}$ \\
\hline
\end{tabular}

$t$ statistics in parentheses

${ }^{*} p<0.10,{ }^{* *} p<0.05,{ }^{* * *} p<0.01$

See also the notes with Table 1. 


\subsection{South-South trade in individual clean energy technologies}

Whilst exports of clean energy technologies, as a group of technologies, was found to not significantly differ in South-South trade, relatively to such exports in North-North trade, such exports did appear to have a strongly different composition in terms of value of exports of individual clean energy technologies. In Table 5, the analysis is therefore repeated for each of those technologies individually. Results show that South-South trade, when compared with North-north trade, contains higher levels of goods classified as hydropower, PV, and electric two-wheelers, whilst it contains lower levels of goods classified as wind power, and hybrid or pure electric vehicles.

These apparent differences in specialization may be explained by a number of different factors. Developing and emerging economies are known to have more limited capabilities in design-intensive technologies such as wind or electric vehicles, whilst they may be better placed to produce manufacturing-intensive products such as PV panels and electric two-wheelers $[65,66]$. Some part of it is due to differences in demand, with Southern nations showing more demand for hydropower technologies (Figure 3), possibly due to more limited concerns over negative environmental and social effects of large dams [67]. Demand for electric vehicles is more limited (Figure 3), likely due to lower per capita incomes and relatively high cost of EV. 
Table 5. Comparison of the value of exports of individual clean energy technologies between different country groups (2014-2018)

\begin{tabular}{|c|c|c|c|c|c|c|c|c|c|}
\hline & (1) & (2) & (3) & (4) & (5) & (6) & (7) & (8) & (9) \\
\hline $\begin{array}{l}\text { Outcome variable: } \\
\text { total value of exports }\end{array}$ & Hydropower & Wind power & PV & $\begin{array}{l}\text { Solar water } \\
\text { heaters }\end{array}$ & Solid biofuels & Bio-ethanol & Biodiesel & $\begin{array}{l}\text { Hybrid or } \\
\text { pure EV }\end{array}$ & $\begin{array}{l}\text { Electric two- } \\
\text { wheelers }\end{array}$ \\
\hline $\begin{array}{l}\text { Traditional gravity model } \\
\text { variables }\end{array}$ & \multicolumn{9}{|c|}{ Omitted (absorbed by fixed effects) } \\
\hline \multirow[t]{2}{*}{ Both WTO members } & -.1976 & -.1976 & -.1976 & -.1976 & -.1976 & -.1976 & -.1976 & -.1976 & -.1976 \\
\hline & $(-0.615)$ & $(-0.615)$ & $(-0.615)$ & $(-0.615)$ & $(-0.615)$ & $(-0.615)$ & $(-0.615)$ & $(-0.615)$ & $(-0.615)$ \\
\hline \multirow[t]{2}{*}{ Common RTA } & .009313 & .009313 & .009313 & .009313 & .009313 & .009313 & .009313 & .009313 & .009313 \\
\hline & $(0.135)$ & $(0.135)$ & $(0.135)$ & $(0.135)$ & $(0.135)$ & $(0.135)$ & $(0.135)$ & $(0.135)$ & $(0.135)$ \\
\hline $\begin{array}{l}\text { All manufactured goods except } \\
\text { focus tech (see model name) }\end{array}$ & \multicolumn{9}{|c|}{ Reference level (omitted due to perfect collinearity) } \\
\hline \multirow{2}{*}{$\begin{array}{l}\text { Exports of focus tech (see model } \\
\text { name) }\end{array}$} & $-7.818^{* * *}$ & $-5.167^{* * *}$ & $-4.395^{* * *}$ & $-7.043^{* * *}$ & $-5.437^{* * *}$ & $-5.527^{* * *}$ & $-4.796^{* * *}$ & $-3.957^{* * *}$ & $-6.53^{* * *}$ \\
\hline & $(-60.444)$ & $(-16.741)$ & $(-30.365)$ & $(-36.507)$ & $(-25.951)$ & $(-26.002)$ & $(-24.186)$ & $(-34.397)$ & $(-32.910)$ \\
\hline Focus tech exports, $\mathrm{N}$-to- $\mathrm{N}$ & \multicolumn{9}{|c|}{ Reference level (omitted due to perfect collinearity) } \\
\hline \multirow[t]{2}{*}{ Focus tech exports, $\mathrm{N}$-to-S } & $1.001^{* * *}$ & -.4416 & $.7629^{* *}$ & $-.5738^{* *}$ & -.9735 & .03228 & $-1.974^{* * *}$ & $-.6154^{* *}$ & $-2.267^{* * *}$ \\
\hline & $(4.017)$ & $(-1.100)$ & $(2.268)$ & $(-2.513)$ & $(-1.333)$ & $(0.076)$ & $(-4.015)$ & $(-2.043)$ & $(-8.529)$ \\
\hline \multirow[t]{2}{*}{ Focus tech exports, S-to-N } & .03883 & $-2.06^{* * *}$ & $1.728^{* * *}$ & $.8112^{*}$ & $.7921^{*}$ & .378 & -.1253 & $-1.337^{* * *}$ & $1.236^{* * *}$ \\
\hline & $(0.101)$ & $(-3.465)$ & $(3.863)$ & $(1.840)$ & (1.799) & (0.709) & $(-0.253)$ & $(-4.313)$ & $(2.630)$ \\
\hline \multirow[t]{2}{*}{ Focus tech exports, S-to-S } & $1.96^{* * *}$ & $-.971^{* *}$ & $1.495^{* * *}$ & .3167 & .7143 & .3084 & -.7871 & $-1.781^{* * *}$ & $.8807^{* * *}$ \\
\hline & $(8.772)$ & $(-2.294)$ & $(4.707)$ & $(0.917)$ & $(1.630)$ & (1.179) & $(-1.521)$ & $(-6.645)$ & (2.689) \\
\hline \multirow[t]{2}{*}{ Constant } & $22.25^{* * *}$ & $22.25^{* * *}$ & $22.22^{* * *}$ & $22.25^{* * *}$ & $22.24^{* * *}$ & $22.25^{* * *}$ & $22.24^{* * *}$ & $22.24^{* * *}$ & $22.25^{* * *}$ \\
\hline & $(69.958)$ & $(69.947)$ & $(69.858)$ & $(69.958)$ & $(69.943)$ & (69.946) & $(69.940)$ & (69.918) & (69.954) \\
\hline Observations & 132920 & 132920 & 132920 & 132920 & 132920 & 132920 & 132920 & 132920 & 132920 \\
\hline Fixed effects & $\begin{array}{l}\text { Country-time } \\
\& \text { country- } \\
\text { pair }\end{array}$ & $\begin{array}{l}\text { Country-time } \\
\& \text { country- } \\
\text { pair }\end{array}$ & $\begin{array}{l}\text { Country-time } \\
\text { \& country- } \\
\text { pair }\end{array}$ & $\begin{array}{l}\text { Country-time } \\
\& \text { country- } \\
\text { pair }\end{array}$ & $\begin{array}{l}\text { Country-time } \\
\& \text { country- } \\
\text { pair }\end{array}$ & $\begin{array}{l}\text { Country-time } \\
\& \text { country- } \\
\text { pair }\end{array}$ & $\begin{array}{l}\text { Country-time } \\
\& \text { country- } \\
\text { pair }\end{array}$ & $\begin{array}{l}\text { Country-time } \\
\& \text { country- } \\
\text { pair }\end{array}$ & $\begin{array}{l}\text { Country-time } \\
\text { \& country- } \\
\text { pair }\end{array}$ \\
\hline
\end{tabular}

tstatistics in parentheses

${ }^{*} p<0.10,{ }^{* *} p<0.05,{ }^{* * *} p<0.01$

See also the notes with Table 1. 


\subsection{Discussion}

There are a number of limitations to the analysis presented here. First, as has been discussed thoroughly in previous work, the system of HS headings may not always precisely identify all, or only, clean energy technologies; see also the summary in Section 2.2. The choice to select HS headings that only or predominantly include clean energy technologies, however, likely remains the most accurate method to gauge total global flows of trade in these products.

Second, whilst the analysis here uses values of trade flows in order to make statements about the relative cleanliness of South-South trade, it should be clear that such trade values cannot exactly be translated into e.g., carbon savings resulting from such exports. Each of the different technologies may have a very different level of carbon emissions saved for every dollar spent on equipment [68], and these values may change over time at different rates for different technologies [69]. Similarly, the trade value in conventional energy technologies (Figure 4) does not necessarily equate with total emissions resulting from those exports. More advanced versions of conventional energy technologies may be both less emission intensive and more costly.

Lastly, although the analysis here is used to highlight that levels of clean energy technologies in South-South trade has grown rapidly in recent years, to a point where it is no longer statistically significantly different from other trade flows, this conclusion may fairly readily change again. Currently, PV products form the bulk of global trade in clean energy goods, and Southern countries perform very well in trade thereof (Figure 3). Northern countries currently outperform Southern countries in the export of electric vehicles, however. As trade in electric vehicles is rapidly growing, and seen the volume of trade in transport versus power generation technologies (Figure 4), it is entirely possible that Northern countries will once again take a leading position in exports of clean energy technologies in the near future. 


\section{Conclusion}

As developing and emerging economies are experiencing rapid economic, these countries are seeing more economic integration, including rapid growth in the total value of South-South trade. The analysis here finds no evidence to support concerns that this might encourage the use of dirty, conventional energy technologies, and lock developing countries into high carbon growth paths. When compared with levels of export seen in North-North trade, exports of clean energy technologies in South-South trade are low relative to total exports, but not significantly different relative to exports of manufactured goods or relative to exports of conventional energy technologies. This reiterates that nations in the global South remain more limited in their manufacturing capabilities compared to nations in the global North, but does not support the notion that they are locked into outdated and dirty manufacturing industries. South-south trade in clean energy technologies was relatively low up until the first half of the 2010's, but no longer in recent years.

The results presented focused on trade, and therefore provide only a part of the story of ongoing economic integration of countries in the global South. Other forms of integration, for example technology transfer and collaboration, or foreign direct investment in for example power generation projects, should continue to be scrutinized for their environmental effects. Such assessments would similarly benefit from comparing flows of knowledge or finance between Southern countries with other flows, in order to comment on the environmental effects of South-South integration.

The analysis here identified that Northern and Southern country groups have different levels of specialization for different clean energy technologies. A useful next research step would be to identify technological characteristics [70], or country characteristics that explain these differences.

\section{Acknowledgements}

This research was supported by Aalborg University (AAU Grant 771107), and by funding under the Energy Transition Hub at the Australian National University. These financiers had no involvement in research design or reporting. 


\section{References}

[1] W. Brandt, North-South: a programme for survival: report of the Independent Commission on International Development Issues., (1980).

[2] K. Gray, B.K. Gills, South-South cooperation and the rise of the Global South, (2016).

[3] World Bank, Global Development Horizons 2011 -- Multipolarity: The New Global Economy, Washington D.C., 2011.

[4] F. Demir, C. Hu, Institutional Differences and the Direction of Bilateral Foreign Direct Investment Flows: Are South-South Flows any Different than the Rest?, World Econ. 39 (2016) 2000-2024.

[5] UNCTAD, World Investment Report 2019, Geneva, 2019. https://unctad.org/en/pages/PublicationWebflyer.aspx?publicationid=2460.

[6] F. Urban, G. Siciliano, K. Sour, P.D. Lonn, M. Tan-Mullins, G. Mang, South-South Technology Transfer of Low-Carbon Innovation: Large Chinese Hydropower Dams in Cambodia, Sustain. Dev. 23 (2015) 232-244.

[7] T.L. Brewer, Climate change technology transfer: a new paradigm and policy agenda, Clim. Policy. 8 (2008) 516-526.

[8] P. Kowalski, B. Shepherd, South-South trade in goods, (2006).

[9] H.W. Singer, P. Gray, Trade policy and growth of developing countries: some new data, World Dev. 16 (1988) 395-403.

[10] G. Chichilnisky, North-south trade and the global environment, in: Econ. Int. Trade Environ., CRC Press, 2001: pp. 101-124.

[11] M. Lovely, D. Popp, Trade, technology, and the environment: Does access to technology promote environmental regulation?, J. Environ. Econ. Manage. 61 (2011) 16-35. https://doi.org/http://dx.doi.org/10.1016/j.jeem.2010.08.003.

[12] J. Sauvage, The stringency of environmental regulations and trade in environmental goods, (2014).

[13] UNEP, Trade in Environmentally Sound Technologies: Implications for Developing Countries, 2018.

[14] UNEP, South-South trade in renewable energy - a trade flow analysis of selected environmental goods, (2014).

[15] K. Kim, Y. Kim, Role of policy in innovation and international trade of renewable energy technology: Empirical study of solar PV and wind power technology, Renew. Sustain. Energy Rev. 44 (2015) 717-727.

[16] F. Urban, China's rise: Challenging the North-South technology transfer paradigm for climate change mitigation and low carbon energy, Energy Policy. 113 (2018) 320-330.

https://doi.org/https://doi.org/10.1016/j.enpol.2017.11.007.

[17] J. Meng, Z. Mi, D. Guan, J. Li, S. Tao, Y. Li, K. Feng, J. Liu, Z. Liu, X. Wang, The rise of SouthSouth trade and its effect on global CO 2 emissions, Nat. Commun. 9 (2018) 1-7.

[18] E. Martinot, J.E. Sinton, B.M. Haddad, International technology transfer for climate change mitigation and the cases of Russia and China, Annu. Rev. Energy Environ. 22 (1997) 357-401.

[19] G. Wilkins, Technology transfer for renewable energy, Routledge, 2010.

[20] J.I. Lewis, Technology acquisition and innovation in the developing world: Wind turbine development in China and India, Stud. Comp. Int. Dev. 42 (2007) 208232. https://doi.org/10.1007/s12116-007-9012-6.

[21] J.I. Lewis, Building a national wind turbine industry: experiences from China, India and South Korea, Int. J. Technol. Glob. 5 (2011) 281305.

[22] K. Hochstetler, South-south trade and the environment: A Brazilian case study, Glob. Environ. Polit. 13 (2013) 30-48.

[23] B.R. Copeland, The pollution haven hypothesis, Handb. Trade Environ. (2008) 60-70.

[24] R. Quitzow, Dynamics of a policy-driven market: The co-evolution of technological innovation systems for solar photovoltaics in China and Germany, Environ. Innov. Soc. Transitions. 17 (2015) 126-148.

[25] D. Tyfield, A. Ely, S. Geall, Low carbon innovation in China: from overlooked opportunities and challenges to transitions in power relations and practices, Sustain. Dev. 23 (2015) 206-216.

[26] D. Tyfield, Innovating innovation-Disruptive innovation in China and the low-carbon 
transition of capitalism, Energy Res. \{\&\} Soc. Sci. 37 (2018) 266-274.

https://doi.org/10.1016/j.erss.2017.10.024.

[27] D.-H. Kim, Y.-B. Suen, S.-C. Lin, Carbon dioxide emissions and trade: Evidence from disaggregate trade data, Energy Econ. 78 (2019) 13-28.

[28] IMF, World Economic Outlook: Database-WEO Groups and Aggregates Information, 2019. https://www.imf.org/external/pubs/ft/weo/2019/01/weodata/groups.htm.

[29] UN Trade Statistics Branch, UN Comtrade database, (2019). https://comtrade.un.org/data/ (accessed August 19, 2019).

[30] N. Dados, R. Connell, The global south, Contexts. 11 (2012) 12-13.

[31] J.-P. Therien, Beyond the North-South divide: the two tales of world poverty, Third World Q. 20 (1999) 723-742.

[32] J.E. Goldthorpe, J.H. Goldthorpe, The sociology of the third world: Disparity and involvement, CUP Archive, 1975.

[33] World Bank, World Development Indicators, (2019). http://datatopics.worldbank.org/worlddevelopment-indicators/ (accessed August 13, 2019).

[34] World Bank, Country Classification: World Bank Country and Lending Groups - historical classification by income in XLS format, (2019).

https://datahelpdesk.worldbank.org/knowledgebase/articles/906519 (accessed August 13, 2019).

[35] UN Trade Statistics Branch, Harmonized Commodity Description and Coding Systems (HS), (2019). https://unstats.un.org/unsd/tradekb/Knowledgebase/50018/HarmonizedCommodity-Description-and-Coding-Systems-HS (accessed August 15, 2019).

[36] I. Wind, HS Codes and the Renewable Energy Sector, Res. Anal. Int. Cent. Trade Sustain. Dev. (2008).

[37] Q. Li, Z. Wang, J. Shuai, L. Ding, Z. Leng, C. Shuai, P. Zhao, Trade Complementarity of Sino-US Wind Energy Products: based on UN Comtrade Data, Int. Energy J. 18 (2018).

[38] J. Shuai, C. Chen, J. Cheng, Z. Leng, Z. Wang, Are China's solar PV products competitive in the context of the Belt and Road Initiative?, Energy Policy. 120 (2018) 559-568.

[39] J.F. Kirkegaard, L. Weischer, T. Hanemann, It should be a breeze: harnessing the potential of open trade and investment flows in the wind energy industry, (2009).

[40] USITC, Renewable Energy Services: An Examination of US and Foreign Markets, US International Trade Commission, 2005.

[41] R. Steenblik, Environmental goods: A comparison of the APEC and OECD lists, OECD Publishing, 2005.

[42] P. Lako, Mapping climate-mitigation technologies/goods within the energy supply sector, Petten: ECN, 2008.

[43] V. Costantini, F. Crespi, Environmental regulation and the export dynamics of energy technologies, Ecol. Econ. 66 (2008) 447-460.

[44] B. Algieri, A. Aquino, M. Succurro, Going "green": trade specialisation dynamics in the solar photovoltaic sector, Energy Policy. 39 (2011) 7275-7283. https://doi.org/10.1016/J.ENPOL.2011.08.049.

[45] M. Glachant, A. Dechezleprêtre, What role for climate negotiations on technology transfer?, Clim. Policy. 17 (2017) 962-981.

[46] K. Head, T. Mayer, Gravity equations: Workhorse, toolkit, and cookbook, in: Handb. Int. Econ., Elsevier, 2014: pp. 131-195.

[47] Y. V Yotov, R. Piermartini, J.-A. Monteiro, M. Larch, An advanced guide to trade policy analysis: The structural gravity model, World Trade Organization Geneva, 2016.

[48] J.J. Tinbergen, Shaping the world economy; suggestions for an international economic policy, (1962).

[49] M. Larch, J. Wanner, Y. V Yotov, T. Zylkin, Currency Unions and Trade: A PPML Re-assessment with High-dimensional Fixed Effects, Oxf. Bull. Econ. Stat. 81 (2019) 487-510.

[50] K. Kepaptsoglou, M.G. Karlaftis, D. Tsamboulas, The gravity model specification for modeling international trade flows and free trade agreement effects: a 10-year review of empirical studies, Open Econ. J. 3 (2010).

[51] C. Carrere, Revisiting the effects of regional trade agreements on trade flows with proper specification of the gravity model, Eur. Econ. Rev. 50 (2006) 223-247.

[52] J.E. Anderson, E. Van Wincoop, Gravity with gravitas: a solution to the border puzzle, Am. 
Econ. Rev. 93 (2003) 170-192.

[53] J. McCallum, National borders matter: Canada-US regional trade patterns, Am. Econ. Rev. 85 (1995) 615-623.

[54] J.-F. Brun, C. Carrère, P. Guillaumont, J. De Melo, Has distance died? Evidence from a panel gravity model, World Bank Econ. Rev. 19 (2005) 99-120.

[55] J.M.C.S. Silva, S. Tenreyro, The log of gravity, Rev. Econ. Stat. 88 (2006) 641-658.

[56] E. Gómez-Herrera, Comparing alternative methods to estimate gravity models of bilateral trade, Empir. Econ. 44 (2013) 1087-1111.

[57] R. Baldwin, D. Taglioni, Gravity for dummies and dummies for gravity equations, National bureau of economic research, 2006.

[58] S.L. Baier, J.H. Bergstrand, Do free trade agreements actually increase members' international trade?, J. Int. Econ. 71 (2007) 72-95.

[59] R. Glick, A.K. Rose, Currency unions and trade: A post-EMU reassessment, Eur. Econ. Rev. 87 (2016) 78-91.

[60] S. Correia, P. Guimarães, T. Zylkin, PPMLHDFE: Fast poisson estimation with high-dimensional fixed effects, ArXiv Prepr. ArXiv1903.01690. (2019).

[61] CEPII, The CEPII Gravity Dataset. Harmonized data for the estimation of gravity equations: GDP, population, trade and money agreements, for each couple of country, from 1948 to 2015, (2019). http://www.cepii.fr/cepii/en/bdd\%7B_\%7Dmodele/bdd.asp (accessed May 21, 2019).

[62] C. Binz, T. Tang, J. Huenteler, Spatial lifecycles of cleantech industries-The global development history of solar photovoltaics, Energy Policy. 101 (2017) 386-402.

[63] M. Daily, U.S. sets new tariffs on Chinese solar imports, Reuters. (2012). https://www.reuters.com/article/us-china-trade/u-s-sets-new-tariffs-on-chinese-solarimports-idUSBRE84G19U20120517.

[64] K.J. McCarthy, On the influence of the European trade barrier on the chinese pv industry: Is the solution to the solar-dispute "successful"?, Energy Policy. 99 (2016) 154-157.

[65] T.S. Schmidt, J. Huenteler, Anticipating industry localization effects of clean technology deployment policies in developing countries, Glob. Environ. Chang. 38 (2016) 8-20.

[66] C. Binz, B. Truffer, Global Innovation Systems-A conceptual framework for innovation dynamics in transnational contexts, Res. Policy. 46 (2017) 1284-1298. https://doi.org/10.1016/j.respol.2017.05.012.

[67] P.M. Fearnside, Environmental and social impacts of hydroelectric dams in Brazilian Amazonia: Implications for the aluminum industry, World Dev. 77 (2016) 48-65.

[68] F. Kesicki, P. Ekins, Marginal abatement cost curves: a call for caution, Clim. Policy. 12 (2012) 219-236.

[69] E.S. Rubin, I.M.L. Azevedo, P. Jaramillo, S. Yeh, A review of learning rates for electricity supply technologies, Energy Policy. 86 (2015) 198-218.

[70] J. Huenteler, T.S. Schmidt, J. Ossenbrink, V.H. Hoffmann, Technology life-cycles in the energy sector-Technological characteristics and the role of deployment for innovation, Technol. Forecast. Soc. Change. 104 (2016) 102-121.

[71] WTO, Members and Observers, (2019). https://www.wto.org/english/thewto\%7B_\%7De/whatis\%7B_\%7De/tif\%7B_\%7De/org6\%7B_ \%7De.htm (accessed January 20, 2020).

[72] EU, The 28 member countries of the EU, (n.d.). https://europa.eu/european-union/abouteu/countries\%7B_\%7Den\%7B\#\%7Dthe-28-member-countries-of-the-eu (accessed January 20, 2020).

[73] WTO, Regional trade agreements database, (2019). https://www.wto.org/english/tratop\%7B_\%7De/region\%7B_\%7De/region\%7B_\%7De.htm (accessed January 20, 2020). 


\section{Appendix A. Country list used in the definition of the global North and South}

Definition of the Global North: this analysis follows the definition of 'Advanced economies' in the IMF's World Economic Outlook of 2019 [28]. This list is: Australia, Austria, Belgium, Canada, Cyprus, Czech Republic, Denmark, Estonia, Finland, France, Germany, Greece, Hong Kong SAR, Iceland, Ireland, Israel, Italy, Japan, Korea (Republic of), Latvia, Lithuania, Luxembourg, Macao SAR, Malta, Netherlands, New Zealand, Norway, Portugal, Puerto Rico, San Marino, Singapore, Slovak Republic, Slovenia, Spain, Sweden, Switzerland, Taiwan Province of China, United Kingdom, United States. All other countries are classified as the Global South. 


\section{Appendix B. Proxy HS headings for trade in clean transport technologies prior to HS2017}

The revision of the Harmonized System of 2017 introduced new HS headings for trade in pure electric passenger cars (HS870380), plug-in hybrid petrol cars (HS870360), plug-in hybrid diesel cars (HS870370), pure electric buses (HS870240), hybrid electric buses (HS870220 \& HS870230), and electric two-wheelers (HS871160) [35]. Prior to the introduction of the HS headings, trade in electric and hybrid cars, buses, and two-wheelers will therefore have occurred under related, unspecific HS headings.

Trade in two-wheelers in earlier HS classification systems falls under chapter 8711, which is sub-divided into different engine capacities. The lowest capacity engines are traded under HS871110, for "Motorcycles (including mopeds) [with an] engine not exceeding 50 $\mathrm{cc}^{\prime \prime}$, whilst the highest capacity engines are traded under HS871150, for "Motorcycles (including mopeds) [with an] engine exceeding 800cc". Electric bikes do not fit under any of these classes and would likely rather be traded under the heading "HS 871190, for Motorcycles (including mopeds) and cycles; not elsewhere specified (n.e.s.) in heading no. 8711".

This is made more likely when comparing the volumes of trade of the heading for bikes 'not elsewhere specified' with the volume of trade in the dedicated HS heading for electric two-wheelers (Figure B.1.). The drastic reduction in trade reported HS871190 from 2017 onwards, suggests that this category was predominantly electric two-wheelers, that are now reported under the dedicated HS heading for electric twowheelers.

The same idea, and similar drop of in the category for vehicles 'not elsewhere specified' can be seen in trade reported for passenger cars (Figure B.1.).

For hybrid and pure electric busses, the same does not apply. Prior to 2017, any bus with a diesel engine would be reported under HS 870210, any bus using any other fuel or propulsion system would be recorded under buses 'not elsewhere specified'. This latter category does not show a marked drop after the introduction of HS headings specifically for electric buses, and it can therefore not be considered likely that the 'not elsewhere specified' category contained predominantly, or even substantial shares, of electric buses. This proxy heading is therefore not used in the analysis here. 


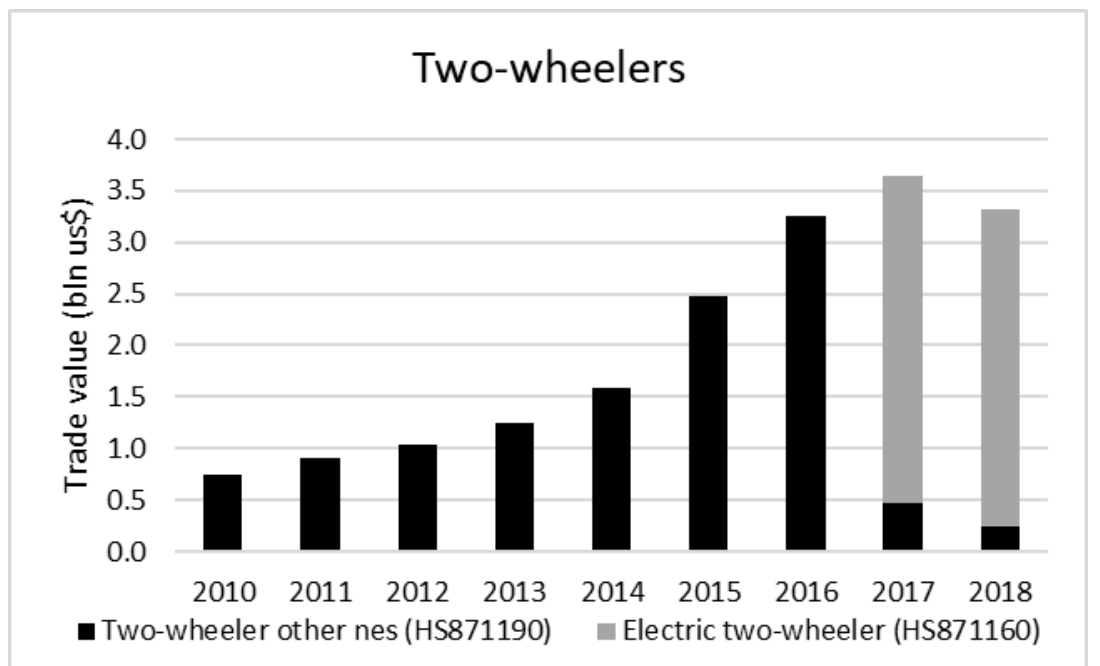

Figure B.1. Trade value in electric two-wheelers, incl. proxy HS headings as used

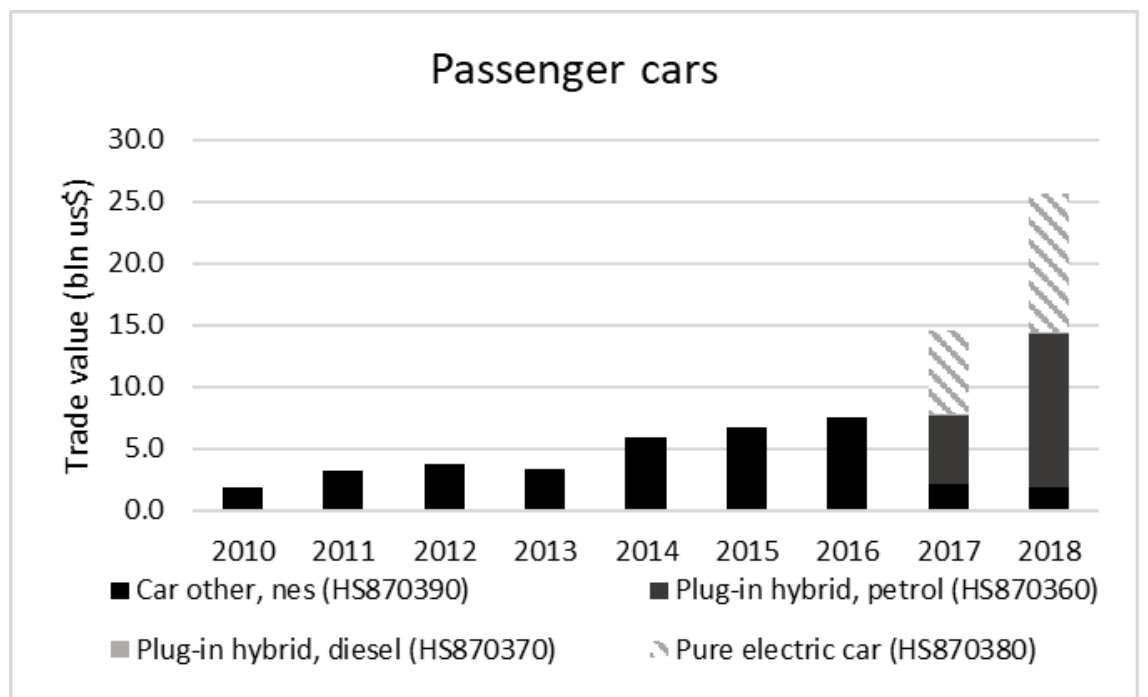

Figure B.2. Trade value in electric passenger cars, incl. proxy HS headings as used

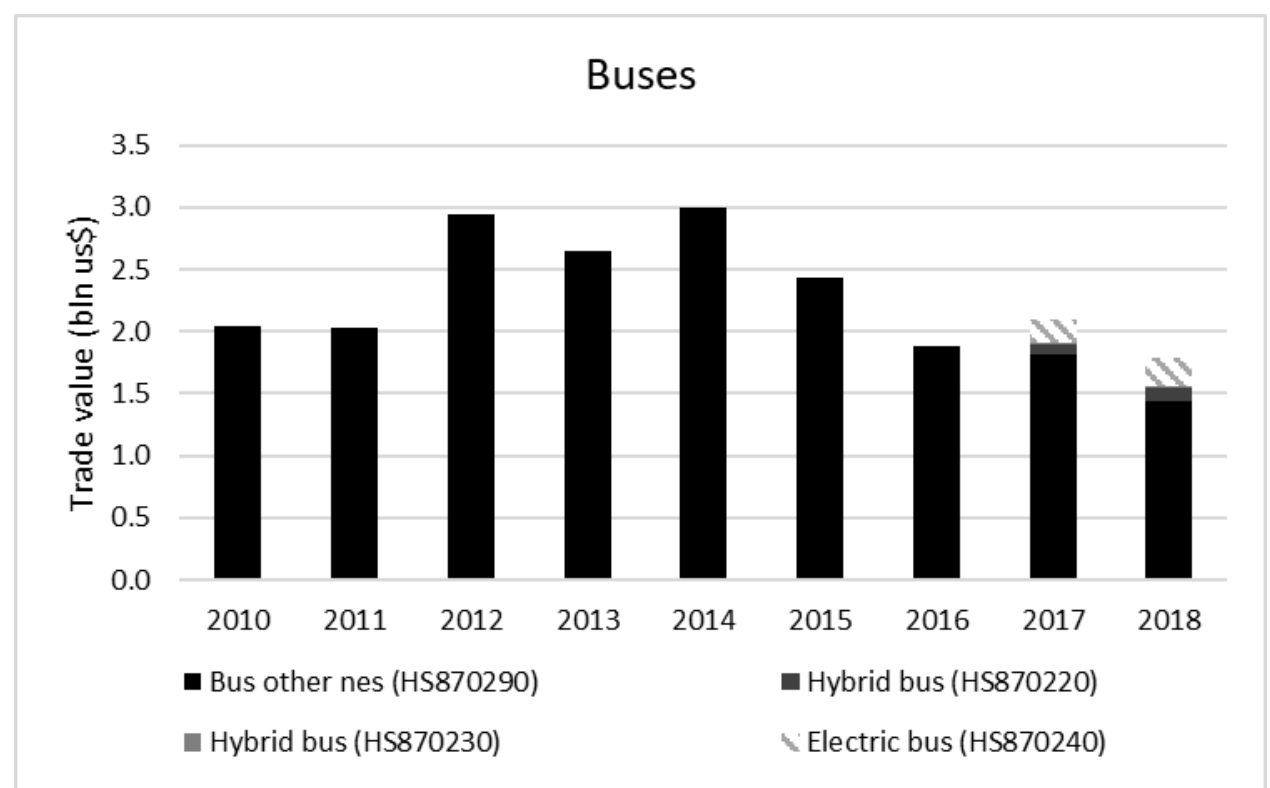

Figure B.3. Trade value in electric buses, incl. possible proxy HS headings (not used) 


\section{Appendix C. Variables definition and data sources}

\section{Table C.1. Variables definition and data sources}

\begin{tabular}{|c|c|c|}
\hline Variable & Definition & Notes and data source \\
\hline \multicolumn{3}{|l|}{ Outcome variable } \\
\hline Total value of exports & $\begin{array}{l}\text { Volume of trade in constant } 2010 \text { US\$. } \\
\text { For each regression analysis reported here, trade } \\
\text { values are summarized to two lines for every } \\
\text { exporter, importer, and year, e.g., to one } \\
\text { observation for total trade in clean energy } \\
\text { technologies, and one observation for total trade in } \\
\text { all other goods. }\end{array}$ & $\begin{array}{l}\text { Source: UN Comtrade database } \\
\text { [29]. }\end{array}$ \\
\hline \multicolumn{3}{|l|}{ Explanatory variables } \\
\hline $\mathrm{GDP}_{\exp } * \mathrm{GDP}_{\mathrm{imp}}$ & $\begin{array}{l}\text { Natural log of the GDP of the exporter (constant } \\
2010 \text { US\$) multiplied by the GDP of the importer } \\
\text { (constant } 2010 \text { US\$) }\end{array}$ & $\begin{array}{l}\text { Source: World Development } \\
\text { Indicators dataset of the World } \\
\text { Bank [33]. }\end{array}$ \\
\hline Distance (weighted) & $\begin{array}{l}\text { Distance between the two countries, calculated } \\
\text { with population-weighted distances between each } \\
\text { of the main agglomerations in each country, in km, } \\
\text { natural log }\end{array}$ & \multirow[t]{5}{*}{$\begin{array}{l}\text { Source: Gravity Dataset from } \\
\text { CEPII [61]. }\end{array}$} \\
\hline Shared border & $\begin{array}{l}\text { Dummy variable, } 1 \text { if exporter and importer are } \\
\text { contiguous }\end{array}$ & \\
\hline Shared colonial past & $\begin{array}{l}\text { Dummy variable, } 1 \text { if exporter and importer have or } \\
\text { ever had a colonial relationship }\end{array}$ & \\
\hline Common currency & $\begin{array}{l}\text { Dummy variable, } 1 \text { if exporter and importer use the } \\
\text { same currency }\end{array}$ & \\
\hline Common language & $\begin{array}{l}\text { Dummy variable, } 1 \text { if exporter and importer use the } \\
\text { same official or primary, or a secondary language } \\
\text { spoken by at least } 20 \% \text { of the population }\end{array}$ & \\
\hline Both WTO members & $\begin{array}{l}\text { Dummy variable, } 1 \text { if exporter and importer are } \\
\text { both members of the WTO in that year }\end{array}$ & $\begin{array}{l}\text { Source: Gravity Dataset from } \\
\text { CEPII [61], updated for } 2015 \\
\text { onwards with [71]. }\end{array}$ \\
\hline Both EU members & $\begin{array}{l}\text { Dummy variable, } 1 \text { if exporter and importer are } \\
\text { both members of the EU in that year }\end{array}$ & $\begin{array}{l}\text { Source: Gravity Dataset from } \\
\text { CEPII [61], updated for } 2015 \\
\text { onwards with [72]. }\end{array}$ \\
\hline Common RTA & $\begin{array}{l}\text { Dummy variable, } 1 \text { if exporter and importer are } \\
\text { both members of a common regional trade } \\
\text { agreement in that year }\end{array}$ & $\begin{array}{l}\text { Source: Gravity Dataset from } \\
\text { CEPII [61], updated for } 2015 \\
\text { onwards with [73]. }\end{array}$ \\
\hline $\begin{array}{l}\text { North-to-North exports; } \\
\text { North-to-South exports; } \\
\text { South-to-North exports; } \\
\text { South-to-South exports }\end{array}$ & $\begin{array}{l}\text { Dummy variable, } 1 \text { if exporter and importer are } \\
\text { both Northern countries for North-to-North exports } \\
\text { (and similar for the other flows) }\end{array}$ & See IMF definition in Appendix A \\
\hline $\begin{array}{l}\text { All manufactured goods except } \\
\text { clean energy goods }\end{array}$ & $\begin{array}{l}\text { Dummy variable, } 1 \text { if the export value is the sum of } \\
\text { all exports for goods other than goods traded under } \\
\text { HS headings classified as clean energy }\end{array}$ & See HS headings in Table 1 \\
\hline Clean energy goods & $\begin{array}{l}\text { Dummy variable, } 1 \text { if the export value is the sum of } \\
\text { all exports of goods traded under HS headings } \\
\text { classified as clean energy (see Table 1) }\end{array}$ & See HS headings in Table 1 \\
\hline $\begin{array}{l}\text { Clean energy exports, } \mathrm{N} \text {-to-N; } \\
\text { Clean energy exports, } \mathrm{N} \text {-to-S; } \\
\text { Clean energy exports, S-to-N; } \\
\text { Clean energy exports, S-to-S }\end{array}$ & $\begin{array}{l}\text { Dummy variable, } 1 \text { if both the dummy variable for } \\
\text { North-to-North exports is } 1 \text { and the dummy } \\
\text { variable for Clean energy goods is } 1 \text { (and similar for } \\
\text { the other flows) }\end{array}$ & See above \\
\hline
\end{tabular}

